This article was downloaded by: [University of Toronto Libraries]

On: 02 February 2015, At: 20:17

Publisher: Routledge

Informa Ltd Registered in England and Wales Registered Number: 1072954

Registered office: Mortimer House, 37-41 Mortimer Street, London W1T

3J H, UK

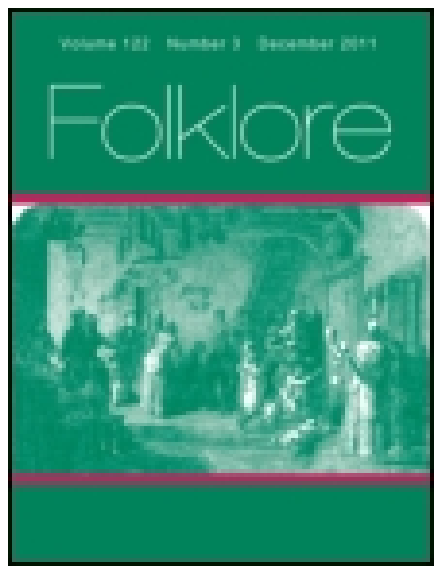

\title{
Folklore
}

Publication details, including instructions for authors and subscription information:

http:// www. tandfonline.com/loi/ rfol20

\section{A Note On Folk-Lore Gleanings From County Leitrim}

Mabel Peacock

Published online: 14 Feb 2012.

To cite this article: Mabel Peacock (1893) A Note On Folk-Lore Gleanings From County Leitrim, Folklore, 4:3, 322-327, DOI: 10.1080/ 0015587X.1893.9720168

To link to this article: http:// dx. doi.org/ 10.1080/0015587X. 1893.9720168

\section{PLEASE SCROLL DOWN FOR ARTICLE}

Taylor \& Francis makes every effort to ensure the accuracy of all the information (the "Content") contained in the publications on our platform. However, Taylor \& Francis, our agents, and our licensors make no representations or warranties whatsoever as to the accuracy, completeness, or suitability for any purpose of the Content. Any opinions and views expressed in this publication are the opinions and views of the authors, and are not the views of or endorsed by Taylor \& Francis. The accuracy of the Content should not be relied upon and should be independently verified with primary sources of information. Taylor and Francis shall not be liable for any losses, actions, claims, proceedings, demands, costs, expenses, damages, and other liabilities whatsoever or howsoever caused arising directly or indirectly in connection with, in relation to or arising out of the use of the Content.

This article may be used for research, teaching, and private study purposes. Any substantial or systematic reproduction, redistribution, reselling, loan, sub-licensing, systematic supply, or distribution in any form to anyone is 
expressly forbidden. Terms $\&$ Conditions of access and use can be found at http://www.tandfonline.com/page/terms-and-conditions 


\section{THE GLASS MOUNTAIN.}

\section{A Note on Folk-Lore Gleanings from County LEITRIM.}

TH HE following imperfect variant of The Glass Mountain was related to me when I was a child by a rough, illiterate, farmhouse servant, a native of Brigg in North Lincolnshire, or of one of the adjacent villages. The story has no point of resemblance with any of our local folkbeliefs, so, I imagine, the girl heard it from a member of the colony of Irish labouring people at Brigg, an opinion which is confirmed by the fact that she told the tale with an air of great reserve and mystery, as something particularly extraordinary and uncanny, cautioning me never to "let on" that I was acquainted with it, which she would scarcely have thought of doing had one of our own commonplace traditions of boggard, ghost, or wizard been in question.

The legend ran in this fashion :

A very long time back, I don't know how long, there was a woman who lived in a lone cottage with her three daughters. Well, one evening when it was getting on to dusk, a man knocked at the door and asked if he could not spend the night there, as he had come a long way, and no other shelter was near at hand. The woman did not much like taking a stranger in, but hers was the only house for miles round, so she could not very well turn him away; and the end of it was she let him lie down by the fire. Then, when morning came, nothing would do for him but he must have the youngest of the three daughters for his wife ; and the lass, she liked his looks well enough, so it was settled that way. They were married, and he 
took her off home with him. A fine, big place she found his house was, with everything in it anybody could want so she thought she should do well enough there. But there was just one thing that was out of the way queer. When the grey of night-time began to come on, the man said to her: "Now, you have got to choose which way it is to be : I must take the shape of a bull either by day or by night, one or the other; how will you have it?" [See the corresponding incident in Campbell's Popular Tales of the West Highlands, vol. i, p. 63.]

"You shall be a bull by day, and a man by night," the girl answered; and so it always was. At sunrise he turned into a bull, then at sundown he was a man again.

Well, use is everything, so after a while his wife got to think as much of him as if he had been like other folks. However, when a year had gone by, and she was likely to have a bairn, she began to think long of seeing her mother and sisters again, and asked her husband to let her go home to them for her confinement. He did not like that : he was quite against it, for fear she should let out what he was. "If you ever opened your mouth to anyone about what you know, ill-luck would come of it," he said.

But still she hankered after her mother, and begged so hard that, being as she was, he could not deny her, and she got her own way.

Well, that time everything went as right as could be. The child was a boy, and fine and proud she was when her husband came to see it. The only trouble she had was that her mother and sisters were as curious as curious to find out why he never came to see her by daylight ; and they had no end to their questions. So at last, when she was strong again, she was glad to go away home with him.

Still, the year after, the same thing happened again. She took such a longing to be nursed by her mother when the next bairn was to be born, that, willing or not, her husband had to let her have her liking. "But mind," he 
said, "we shall have the blackest of trouble if you ever tell what you know of me." Then she promised by all that was good to keep a quiet tongue about him; and she held to her word. Whenever her mother and sisters began to wonder and to ask, she put them off with one thing or another, so that when she took her second boy home with her she left them no wiser than they were before.

Well, the next year another child was coming, and then she had just the same tale to her husband: she must go back to her mother, she could not bide away from her.

"If you will, why you will," said the man, "but remember what will come of it if you speak ;" and then, though it went sorely against him, he let her and the children go.

This time, do as she would, her mother and sisters gave her no peace ; they were fairly bursting with curiousness to know the far-end of her husband's comings and goings; and at last, on the day her third boy was born, they plagued her so much with their inquisitiveness that she could not hold out, and just told them the truth of it. Well, when evening drew on, she thought her husband would be coming to see the child, but the sunset went by, and the dusk went by, and the night went by, without a sight or sign of him. Then, after that, days and days slipped past, but still he stayed away.

When she was up and about again she grew that sick of waiting and waiting, that she took her bairns with her and set off to seek him. . . . . .

[Here the story is defective. I believe the wife returned to her husband's house, and, finding it desolate, wandered out into the world in search of him, meeting with adventures analogous to those which befel the heroine of the Leitrim legend. My memory takes up the tale at the point where she is endeavouring to release her husband from the spell which prevents him recognising her.]

So she sat down outside his door, combing her hair, and sang:- 
"Bare bull of Orange, return to me,

For three fine babes I have borne to thee,

And climbed a glass hill for thee,

Bare bull of Orange, return to me."

[Compare this rhyme with the ditty sung by the wife in the Welsh story told in Campbell's Popular Tales of the West Highlands, vol. iv, p. 295.]

But his stepmother had given him a sleeping-drink, so he never heard her.... Then on the second night she came to his door again, and sat combing her hair, and sang :-

"Bare bull of Orange, return to me,

For three fine babes I have borne to thee,

And climbed a glass hill for thee,

Bare bull of Orange, return to me."

And this time he turned in his bed and groaned, but his stepmother's sleeping-drink hindered him knowing that he heard his wife's voice. . . . Then on the third night it was her last chance, and she sat outside the threshold of his door, and combed her hair, and sang :-

" Bare bull of Orange, return to me,

For three fine babes I have borne to thee,

And climbed a glass hill for thee,

Bare bull of Orange, return to me."

And he started up and opened his chamber door; and so the stepmother's spells were all broken. He had his shape again by day and by night like other men, and they lived with their three children in peace and quietness ever after.

The invocation, "Bare bull of Orange," commencing the night-song of the wife, has always puzzled me; but if the story is of Irish origin, it is possible that the words represent the sound rather than the sense of some phrase difficult to render out of Erse, when the story was put into English form.

Another legend relating to the "Bull of Orange" is to be 
found in the fifth chapter of Mary Hallock Foote's tale, "The Last Assembly Ball," in The Century Magazine, I889, p. 788. The story is there quoted from a fairylegend, originally related by an Irish woman from County Tyrone, and is adapted by the person to whom she is supposed to have recounted it, so as to serve as an illustration of a situation in the novel.

This episode in the bull's career is as follows :-

Well, once there was a king who had six beautiful daughters; and in one room of the palace stood the wishing-chair on a dais, with a curtain before it, and on her sixteenth birthday each of the princesses, in turn, was allowed to sit in the wishing-chair and wish the wish of a lifetime. The youngest princess was a mad-cap. She made fun of the stupid old chair, and of her sisters' wishes. ... . She said, when her turn came she would wish a wish that would show what the old chair could do.

There was a prince in that county of Ireland very wealthy and powerful, and he was bewitched, so that he was obliged to spend half his time roaming the country in the shape of a terrible wild roan bull, and he was called the Roan Bull of Orange. Now, the youngest princess, when she got into the chair .... wished .... that she might be the bride of the Roan Bull of Orange, and then she flew out of the chair . . . . and said it was all nonsense - the chair was as deaf as a post, and the Roan Bull would never hear of her wish.

However, he came that night, trampling and bellowing about the house, and demanded the princess. The princess went and hid behind her mother's bed. They took the daughter of the hen-wife instead, and dressed her up in the princess's clothes.... ; and when the Bull had carried her on his back across the hills and valleys to his castle, he gave her an ivory wand, and charged her, on her life, to tell him what she would do with it, and she sobbed out she would "shoo" her mother's hens to roost with it. So 
the Roan Bull took her on his back again, and over the mountains with her.... and demanded his princess. After they had heard the hen-wife's daughter's story, they took the daughter of the swineherd, and charged her, if the Roan Bull gave her an ivory wand, she was to say she would guide her milk-white steeds with it ; and so should she save the life of her dear little princess. But she thought as much of her own life, it seems, as she did of the princess's, or perhaps she was so frightened she could not speak anything but the truth; for when the Roan Bull gave her the wand, and glared at her with his awful eyes, she .... whispered she would drive her father's pigs with it. So back she went, like the first one .... and this time the Bull fairly raved for his princess. They had an awful night of it in the palace, for the princess had "got her mad up". . . . She took the Bull by the horns, as it were, and off she went ....; and when the wand was given to her, she said, without the least hesitation, that it would be very convenient to beat the maid with who did her hair, when she pulled the tangles in it. So the Roan Bull knew he had got the right one at last.

In this story, also, there is no explanation of the word "Orange". The hero was the "Bull of Orange", but the wherefore remains enveloped in darkness.

Mabel Peacock. 